\title{
Effects of Beta Glucosidase Inhibitor on Cellulase Enzyme Activity for Preparation of Microcrystalline Cellulose from Water Hyacinth (Eichhornia crassipes)
}

\author{
Annisa Shabrina ${ }^{1}$, Herman Suryadi ${ }^{1, *}$, Sutriyo ${ }^{2}$
}

Annisa Shabrina ${ }^{1}$, Herman Suryadi $^{1, *}$, Sutriyo $^{2}$

'Laboratory of Microbiology and Biotechnology, Faculty of Pharmacy, Universitas Indo-nesia, Depok 16424, INDONESIA.

'Laboratory of Pharmaceutical Technology, Faculty of Pharmacy, Universitas Indonesia, Depok 16424, INDONESIA.

\section{Correspondence}

Herman Suryadi

Laboratory of Microbiology and Biotechnology, Faculty of Pharmacy, Universitas Indonesia, Depok 16424 INDONESIA.

E-mail: hsuryadi@farmasi.ui.ac.id

History

- Submission Date: 05-12-2018;

- Review completed: 12-04-2019;

- Accepted Date: 24-05-2019.

DOI : 10.5530/pj.2019.11.190

Article Available online http://www.phcogj.com/v11/i6

Copyright

(c) 2019 Phcogj.Com. This is an openaccess article distributed under the terms of the Creative Commons Attribution 4.0 International license.

\begin{abstract}
Objective: Microcrystalline cellulose (MCC) was a highly desirable excipient which being used for making tablets with direct compression method in Pharmaceutical manufacture. The purpose of this study was to compare microcrystalline cellulose preparation from water hyacinth powder with and without addition of $\beta$-glucosidase inhibitor followed by identification and characterization of the resulting powders. Methods: The study was began with isolation of potential organisms from soils in mangrove followed by extraction of ${ }^{-}$-glucosidase inhibitor. MCC was prepared through enzymatic hydrolysis of alpha-cellulase with and without addition of beta-glucosidase inhibitor. Identification was done using FTIR, then characterized by organoleptic examination, qualitative analysis, starch test, $\mathrm{pH}$ test, Scanning Electron Microscopy (SEM) analysis of particle size and distribution, X-ray Diffraction (XRD), moisture content, loss on drying test, particle density test, flow rate test and angle of repose test compared to microcrystalline cellulose which had been available on the market. Results: The hydrolysis conditions were carried out at $30^{\circ} \mathrm{C}$, for $2 \mathrm{~h}$ and the powder was dissolved in acetate buffer $\mathrm{pH} 7$ by addition of enzyme and $2.5 \mathrm{ml}$ inhibitor. MCC yield with addition of beta-glucosidase inhibitor $(80 \%)$ was higher than without addition of beta-glucosidase $(68 \%)$ Conclusion: Addition of beta glucosidase inhibitor showed positive impact to increase MCC yield from alpha cellulose sample.

Key words: Microcrystalline cellulose, $\beta$-glucosidase inhibitor, Water hyacinth, Enzyme hydrolyisis, Charaterization
\end{abstract}

\section{INTRODUCTION}

Indonesia is a country with vast waters. Aquatic ecosystems need to be protected from various threats because of their benefits for the people of Indonesia. One of the threats to the waters is the presence of aquatic weeds that grow uncontrollably, namely water hyacinth (Eichhornia crassipes). Water hyacinth grows very fast ( $\pm 3 \%$ per day), so that in a short time water hyacinth can cover the surface of the water. ${ }^{1}$ Uncontrolled populations cause various problems to the environment, such as silting of waters and reducing fish production. One form of countermeasure of the problems was to utilize the chemical content of this plant. Hyacinth was known containing $60 \%$ cellulose, $8 \%$ hemicellulose and $17 \%$ lignin. $^{2}$ The cellulose produced from water hyacinth can be purified and partially polymerized by treating cellulose obtained as pulp. Making microcrystalline cellulose was very important for pharmaceutical preparations, especially tablets. Microcrystalline cellulose is a strong filling material that can be used for making tablets with direct compression method which is the most economical method in making tablets. ${ }^{3}$ One of the methods in making microcrystalline cellulose was by enzymatic hydrolysis. This method has several advantages compared to acid hydrolysis which is working at low temperature and neutral
$\mathrm{pH}$, no sugar degradation at hydrolysis result, low cost and have good yield potency.

In previous studies, isolation of various cellulase enzyme-producing fungi was used for its activities in the manufacture of microcrystalline cellulose from water hyacinth. Isolates with good activity after screening using DNS-Spectrophotometry reduction sugar method are green isolates derived from the soil. ${ }^{4}$ However, the result showed that cellulolitic isolates had high glucose concentrations. This showed that cellulase activity especially $\beta$-glucosidase to degrade cellulose to glucose was still high. To overcome this, an inhibitor of $\beta$-glucosidase may be added which is expected to prevent the degradation of cellulose into glucose in the a-cellulose enzymatic hydrolysis process of water hyacinth and obtained a better rendement value. The addition of the $\beta$-glucosidase inhibitor was performed because this enzyme exhibits various structures and functions in nature, it was particularly interesting to examine primarily to discover it from potential natural resources.

In this study, the development of microcrystalline cellulose from water hyacinth developed using cellulase enzyme hydrolysis. The cellulase enzyme used originated from cellulolytic isolates from previous studies with the addition of inhibitors from potential sources for example from mangrove forest soils. ${ }^{5}$ The source of cellulose used comes 
from water hyacinth. Cellulase with optimal cellulolytic activity is used for a-cellulose hydrolysis and the results obtained are identified by using Fourier-transform infrared spectroscopy (FTIR). After that, characterized by determining each physical parameter of qualitative analysis, organoleptic, particle size and particle distribution, X-ray diffractometer (XRD) analysis, $\mathrm{pH}$ test, ash content, moisture content, Scanning Electron Microscopy (SEM), particle density test, flow rate test, starch test, angle of repose test and loss on drying test. The microcrystalline cellulose character was then compared to the standard Avicel PH 101 character.

\section{MATERIAL AND METHODS}

\section{Sample and chemical materials}

Raw materials used in this study are water hyacinth powder obtained from Balai Tanaman Obat dan Rempah (BALITRO). Sources of microorganism isolates as potential $\beta$-glucosidase inhibitors were obtained from sedimentary soil derived from Mangrove Forest Park in Pantai Indah Kapuk. Sources of cellulolytic cellulol producer isolates using green soil isolates from previous studies ${ }^{6}$ stored at the Microbiology Laboratory, Faculty of Pharmacy, Universitas Indonesia, Depok. Dinitro Salicylic Acid (Sigma-Aldrich, USA), $\beta$-glucosidase enzyme (TCI Chemicals, Japan), Fenil- $\beta$-D-glukopiranosida (SigmaAldrich, USA) and DMSO (Merck, German). Reagents and other chemicals used in the study were technical.

\section{Extraction of $\beta$-glucosidase inhibitor metabolites}

Cultures was grown on nutrient agar medium in $20 \% \mathrm{NaCl}$, then inoculated on $50 \mathrm{~mL}$ of Nutrient Broth medium (NB) in $20 \% \mathrm{NaCl}$. Then, the sample was incubated at incubation at shaker at $30^{\circ} \mathrm{C}$ and 200 $\mathrm{rpm}$ for $48-72 \mathrm{~h}$. The culture was then centrifuged at a speed of 5500 rpm for $30 \mathrm{~min}$. Supernatants containing secondary metabolites were fed into a $250 \mathrm{~mL}$ erlenmeyer flask; then mixed with 25 grams of silica gel 60 (Merck) and stirred with a magnetic stirrer for $30 \mathrm{~min}$. After that, input the contents of the flask into the glass column, washed with $15 \mathrm{~mL}$ of aquades and eluted with $20 \mathrm{~mL}$ of methanol. The methanol fraction was then evaporated using a rotary evaporator and dissolved into Dimethyl Sulfoxide (DMSO) and stored at $-20^{\circ} \mathrm{C}$.

\section{Evaluation of $\beta$-glucosidase}

A mixture of agar powder and nutrient solution with cellulase enzyme dissolved in $\mathrm{pH} 5$ acetate buffer and then adding $1.2 \mathrm{ml}$ of Iron (III) Chloride solution and $40 \mu \mathrm{L} \beta$-glucosidase enzyme ( 0.01 units / $\mathrm{mL}$ ) at $60^{\circ} \mathrm{C}$, then add up to $10 \mathrm{~mL}$ of acetate buffer. The solution is then poured into a petri dish. The metabolite extract is then injected using a $5 \mu \mathrm{L}$ micropipette onto the paper disk. The plate is then incubated at room temperature to determine the main reaction between the enzyme and the inhibitor for $30 \mathrm{~min}$. Then add 1-2 $\mathrm{mL}$ of pNPG solution to cover the agar surface, incubated for $30 \mathrm{~min}$ at room temperature to determine the reaction between substrate and inhibitor. To clarify the clear zone formed, added lugol to show inhibitory activity if clear zone was formed.

\section{Cellulase enzyme extraction}

Extraction started with making spore suspension by adding aquabides into a test tube containing a culture stock of cellulolytic isolates. Then, discratched until the spores dissolved in the aquabides. A total of $10 \mathrm{~mL}$ of suspension of the spore and $10 \mathrm{~mL}$ of $0.1 \%$ of Tween 80 were fed into $200 \mathrm{~mL}$ of nutrient solution. Then stirred at $150 \mathrm{rpm}$ for 2 $\mathrm{h}$ at room temperature. A mixture of $30 \mathrm{~mL}$ was taken and centrifuged at $3000 \mathrm{rpm}$ for $10 \mathrm{~min}$. From centrifugation results obtained supernatant used as a rough enzyme for screening cellulase activity, evaluation of $\beta$ - glucosidase inhibitors and enzymatic hydrolysis of cellulose into microcrystalline cellulose.

\section{Preparation of a-cellulose isolation}

A total of $300 \mathrm{~g}$ of sifted water hyacinth powder then placed in a beaker glass was added with $4 \mathrm{~L}$ of $3.5 \%$ nitric acid (containing 40 mg sodium nitrite) and heated for $2 \mathrm{~h}$ at $90^{\circ} \mathrm{C}$ above the waterbath. After that, the residue is filtered and washed with aquades. The residue is then immersed in $3 \mathrm{~L}$ of a solution containing Sodium Hydroxide and Sodium Sulfite each $2 \% \mathrm{w} / \mathrm{v}$ and heated at $50^{\circ} \mathrm{C}$. for $1 \mathrm{~h}$. Then the residue is filtrated and washed with aquades. Bleaching with $2 \mathrm{~L}$ of water solution with 3.5\% Sodium Hypochlorite 1: 1 and boiled for 10 min followed by filtration and washing of residues using aquades. The obtained residue was added $17.5 \% \mathrm{w} / \mathrm{v} \mathrm{NaOH}$ then heated for $30 \mathrm{~min}$ at $80^{\circ} \mathrm{C}$., after which it was filtrated and washed again with aquades. The resulting residue is $a$-Cellulose. The extraction was continued by mixing a-Cellulose in $2 \mathrm{~L}$ water mixture and 3.5\% 1: 1 Sodium Hypochlorite which was heated at $100^{\circ} \mathrm{C}$ for $5 \mathrm{~min}$. The residue is filtered and washed thoroughly. Then dried in an oven with a temperature of $60^{\circ} \mathrm{C}$ and obtained $\alpha$-cellulose powder). ${ }^{5}$

\section{Microcrystalline cellulose preparation by hydrolysis method of cellulite enzyme}

The $10 \mathrm{~g}$ a-Cellulose was hydrolyzed enzymatically with $0.05 \mathrm{M}$ Sodium Acetate buffer $\mathrm{pH} 7$ of $100 \mathrm{~mL}$ while adding a mixture of cellulase enzyme with $5 \mathrm{~mL}$ inhibitor at $30^{\circ} \mathrm{C}$ and $160 \mathrm{rpm}$ for $2 \mathrm{~h}$ above water-shaking incubator. Thereafter, the mixture was centrifuged at 5,500 $\mathrm{rpm}$ (at a temperature of $7-10^{\circ} \mathrm{C}$ for $30 \mathrm{~min}$ ). The rest of the enzyme was removed by washing residue that settled with the aquades then dried

\section{Identification and characterization}

The identification was performed using FTIR (Shimadzu FTIR-8400s) to determine the functional groups present in microcrystalline cellulose samples compared to the Avicel PH 101 standard.

\section{Scanning electron microscope (SEM)}

The sample was inserted into a room then irradiated with a $10 \mathrm{kV}$ electron beam so that the sample ejected detectable secondary electrons, detonating electrons and a detector scientor, which was then reinforced with an electrical circuit causing a CRT (Catode Ray Tube) image. Shooting was done after selecting a certain part of the object (sample) and magnification was desired so that obtained a good and clear photograph. Identification was compared to Avicel PH 101.

\section{X-Ray diffractometer (XRD)}

The sample was printed on a circular plate mold and flattened until no wave is formed on the sample surface. Measurements were made using XRD Bruker D8 Advance ECO Diffractometer operated in reflection method $(40 \mathrm{kV}, 35 \mathrm{~mA})$ using Cu-Ka radiation $(11=1,54060 \AA$ and 12 $=1,54439 \AA$ ) and using step scan method with initial position $\left({ }^{\circ} 20\right)$ of $5,000^{\circ}$, step size $\left({ }^{\circ} 20\right)$ of $0.020^{\circ}\left(76.8\right.$ s per step) and ending at $\left({ }^{\circ} 20\right)$ of $80.009^{\circ} .^{15}$ The resulting diffraction pattern was compared to Avicel PH 101.

\section{Particle size and distribution analysis}

Preparation was done by dispersing the crystal powder in an appropriate medium which can disperse the sample powder. In this test, ethanol dispersion medium was used. Requirements for particle size distribution testing ranged from 0.01-200 $\mu \mathrm{m}$.

\section{$\mathrm{pH}$ test, ash content and starch test}

The method used in this test is based on the Farmakope Indonesia $2014 .^{6}$ 


\section{Water content and organoleptic}

Moisture content was measured using moisture content (Adam) with a temperature of $105^{\circ} \mathrm{C}$. A number of samples were weighed \pm 1.0 grams on the aluminum plate that had been previously held. Then the appliance is turned on and the tool will measure the water content of the sample. The experiment is repeated using the Avicel PH 101 standard. A good microcrystalline cellulose powder is a white, odorless and tasteless powder.

\section{Particle density}

The density test of powder particles is done by bulk-tapped density. First, the product produced is weighed to meet $60 \%$ of the $50 \mathrm{~m}$ polygonal-grounded measuring cup, then the volume is recorded (bulk volume / Vb). Next, the polygonal grounded measuring cylinder is placed on the tool. Then, the tool is turned on and set to 250 beats / minute, then recorded the final volume (tapped density / Vt). The experiment was repeated using the Avicel PH 101.

\section{Flow rate test}

Microcrystalline cellulose powder weighed approximately $10 \mathrm{~g}$. The powder is fully inserted into the flowmeter. Flowmeter switched on, calculate the time required until all the powders flow down recorded and then calculate the flow rate. The experiment was repeated and compared using Avicel PH 101 powder.

\section{Angle of repose test}

Microcrystalline cellulose powder weighed approximately $10 \mathrm{~g}$. The powder is carefully poured into the flowmeter funnel until the end of the powder conical touches the end of the funnel. Then the end cover of the funnel is opened slowly so that the powder flows down slowly.

\section{Loss on drying test}

A total of 1 gram of sample was included in porcelain crucible, then dried in an oven at $105^{\circ} \mathrm{C}$ for $3 \mathrm{~h}$ until constant weight was obtained.?

\section{RESULTS}

\section{Cellulase enzyme extraction}

Cellulase enzyme extraction was performed by dissolving $10 \mathrm{~mL}$ of spore suspension and $10 \mathrm{~mL}$ of Tween $800.1 \%$ into nutrient solution. The addition of tween $800.1 \%$ was done to increase the permeability of the cells so that the enzyme is easier to get out of the cell wall. From the centrifugation results obtained a supernatant crude cellulase enzyme in which the pellets are formed like thin of thread. The supernatant obtained was then used for evaluation of the action of $\beta$ - glucosidase inhibitor, quantitative screening, optimization for enzymatic hydrolysis and enzymatic hydrolysis of cellulose microcrystalline.

\section{Evaluation of $\beta$-glucosidase inhibitors}

The culture extract obtained, 3 of them showed that they were able to inhibit the action of the enzyme $\beta$-glucosidase. 3 of the culture shows yellowish white color but the color is not clearly visible, Researcher adds lugol reagent to clarify the magnitude of the clear area that is formed and can be seen in Figure 1. Of the three samples that form the yellowish white color, it is known that the sample of the third bundle has an area the biggest clear and clear compared to mold one and mold two. Clearly clear formation of clear zones can be caused by the concentration of PNPG manufacture as a less substrate, because the higher the enzyme's substrate input will be higher (Table 1). ${ }^{18}$

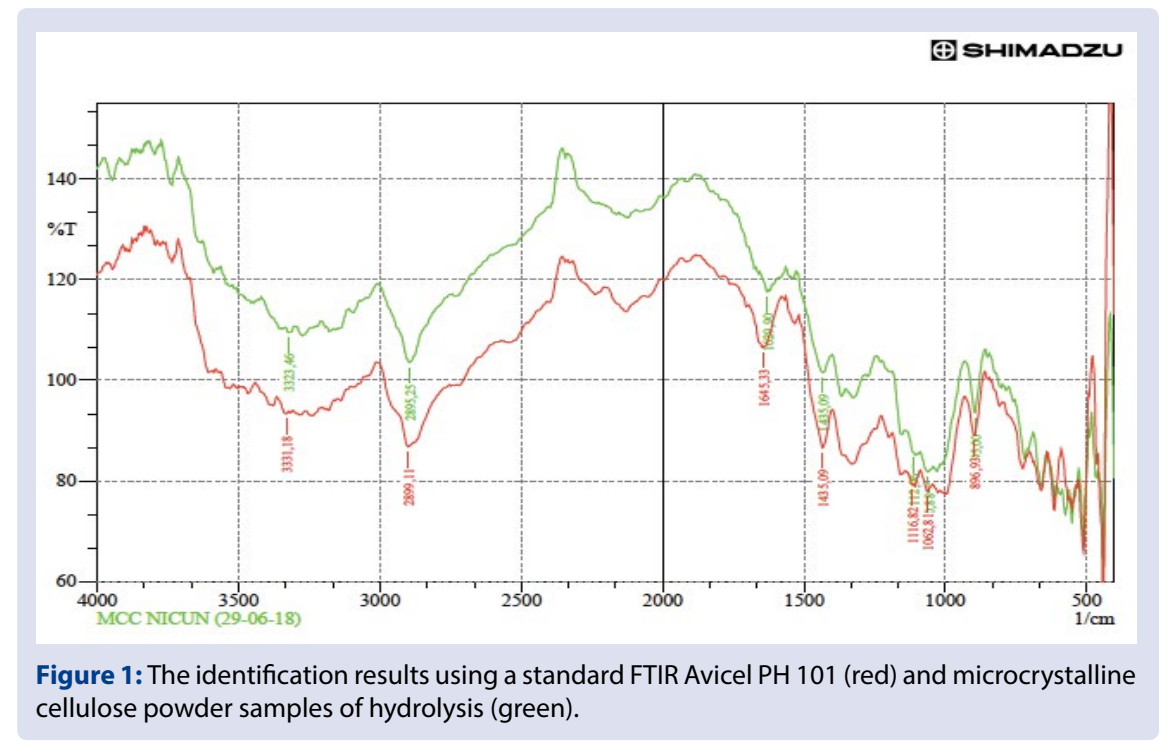

Table 1: Clear zones formed on the evaluation of $\boldsymbol{\beta}$ - glucosidase inhibitors.

\begin{tabular}{cc}
\hline & Clear zones formed $(\mathrm{cm})$ \\
\hline Mould one & 0.44 \\
\hline Mould two & 0.55 \\
Mould three & 0.7 \\
Yeast one & - \\
Mould five & - \\
\hline
\end{tabular}




\section{Preparation of a - cellulose from water hyacinth (Eicchornia crassipes)}

The results obtained from the preliminary process are then weighed and crushed to a fine powder. But in the process, found some difficulties that is difficult to clean the powder because the original color of dark green dust so the color of the powder of the insulation results are less white, while the expected color is white. In addition to the washing process, this can occur due to lack of perfect in the process of delignification. After being isolated the dried powder is very difficult to crushed or blended, so the resulting powder is not smooth. The result of $\alpha$-cellulose isolation obtained from 300 gram of water hyacinth powder was 58,8 gram $(19,6 \%)$.

Making microcrystalline cellulose with enzymatic hydrolysis method by cellulase enzyme and $\beta$ glucosidase inhibitor

Manufacture of microcrystalline cellulose by enzymatic hydrolysis method of cellulase enzyme with addition of inhibitor compared with enzymatic hydrolysis of cellulase enzyme without addition of inhibitor. When compared with the hydrolysis of microcrystalline cellulose samples from water hyacinth without the addition of inhibitor (68\%), a higher yield value was obtained with the addition of an inhibitor $(80 \%)$.

\section{Identification using FTIR}

Based on the literature ${ }^{3}$, the main peaks in the infrared spectrum of microcrystalline cellulose are among $3500-3300 \mathrm{~cm}^{-1}(\mathrm{OH}), 2900$ - $2800 \mathrm{~cm}^{-1}$ (CH aliphatic), $1650 \mathrm{~cm}^{-1}(-\mathrm{O})$ - drag the neighboring hydrogen atom), $900 \mathrm{~cm}^{-1}$ ( $\beta$-glycosidic bond) and $1060 \mathrm{~cm}^{-1}(\mathrm{C}-\mathrm{OH})$.

The interpretation results from above IR spectrum data on Avicel PH 101 standard and microcrystalline cellulose samples of hydrolysis result can be seen in Figure 1. In the standard and sample, in addition to the main peak of microcrystalline cellulose, there was also a peak in the $1435 \mathrm{~cm}^{-1}$ region indicating the presence of clusters in $\mathrm{C}-\mathrm{OH}$, $\mathrm{CH}$, or asymmetric $\mathrm{CH}_{2}$ and clusters in the region of $1116.82 \mathrm{~cm}^{-1}$ at the standard and $1112.96 \mathrm{~cm}^{-1}$ in the sample, indicating the presence of a cyclic monosaccharide group, $\mathrm{C}-\mathrm{C}$, or $\mathrm{C}-\mathrm{O}-\mathrm{C}$ of asymmetry, which belongs to the cellulose component. ${ }^{5}$ Despite the small differences between standards and samples, the FTIR spectrum of the samples shows a common characteristic spectrum of microcrystalline cellulose.

\section{Scanning electron microscope (SEM)}

The result of SEM analysis shows that the morphological structure formed between the standard and the hydrolysis result has similarity. Both are formed small fragments, the fiber content is not much and the form of a rough surface. This indicates that lignocellulose has been destroyed in the preliminary process and hydrolysis is enzymatically successful. ${ }^{7}$ In addition, the particles formed in the resulting hydrolysis sample are the same as the spherical standard. However, the particle distribution seen in the sample is more uneven than the standard, this may be due to a preliminary process between different standards and samples and different sources of powders (Figure 2).

\section{Analysis of X-Ray diffractometer (XRD)}

Based on literature, ${ }^{9}$ From the result of XRD analysis, the amorphous sample is shown on the value of 2 (deg) at 18.882 with intensity 394 . In the hydrolysis result sample there are 2 peaks indicating the existence of crystal character at 21,7731 with intensity 979 and at 22,3246 with 1199 intensity. For amorphous nature there are also 2 peaks at $2 \theta$ (deg) value at 14,8546 and 18,882 Percentage of crystallinity from standard is $79,08 \%$ while sample is $67,47 \%$. The presence of 2 crystalline and amorphous peaks is influenced by the source of samples derived from water hyacinth and the manufacture of $a$-cellulose using a strong base to remove lignin (Figure 3).

\section{Particle size and distribution analysis}

The sample of enzymatic hydrolysis results from the water hyacinth powder, previously dried, crushed and blended, $10 \%$ of the total particle size has a particle size of less than $1.793 \mu \mathrm{m}, 50 \%$ of the total particle size has a particle size of less than $2.579 \mu \mathrm{m}$ and $90 \%$ of the total particle size has a particle size of less than $10.38 \mu \mathrm{m}$ with an average of 5.523 $\mu \mathrm{m}$. The above data shows that the hydrolysis result yields a very fine powder. Very fine particles indicate that cellulosic chain breaking is due to a preliminary process using acid. ${ }^{8}$

\section{Characterization}

Table 2.

\section{DISCUSSION}

From soils in mangrove, single colonies were regenerated, it was found 8 types of mold organisms and 1 type of yeast which all grew on PDA

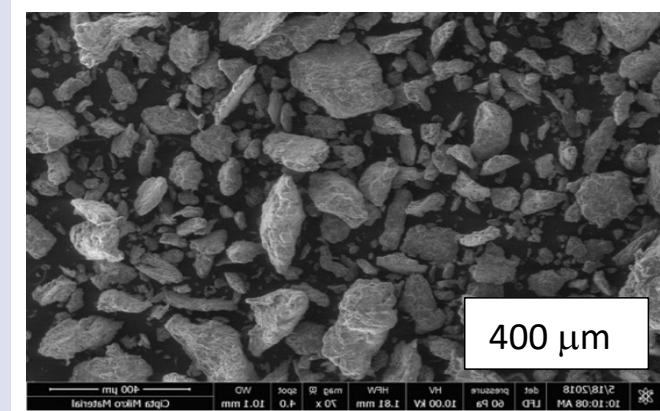

(a)

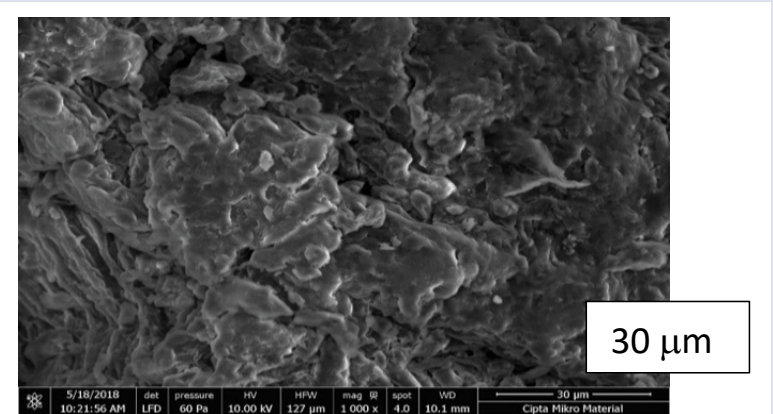

(b)

Figure 2: Results of SEM analysis on microcrystalline cellulose powder samples from water hyacinth with magnification of (a) 70x and (b) $1000 x$. 


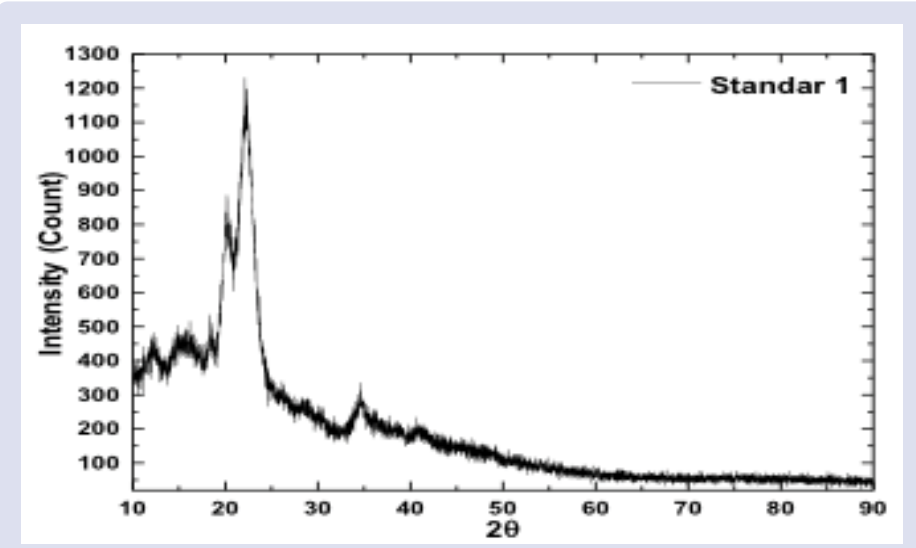

Figure 3: Difractogram of water hyacinth powder from hydrolysis.

Table 2: Results of characterization of microcrystalline cellulose samples from hydrolysis.

\begin{tabular}{ccc}
\hline Test & Requirement & Sample \\
\hline Organoleptic & No color, tastes, and odor & Yellowish color, with no tastes and odor \\
Starch & No color & No color \\
$\mathrm{pH}$ & $\mathrm{pH} \leq 5.0$ dan $\mathrm{pH} 7.5$ & $\mathrm{pH} 7.09$ \\
Loss on drying & $\leq 7.0 \%$ & $4.1636 \%$ \\
Ash content & $\leq 0.1 \%$ & $0.24 \%$ \\
Moisture content & $\leq 5 \%$ & $7.62 \%$ \\
& & $\mathrm{BD}: 0.5643 \mathrm{~g} / \mathrm{cm}^{3}$ \\
Particle density & $\mathrm{BD}: 0.25-0.50 \mathrm{~g} / \mathrm{cm}^{3}$ & $\mathrm{TD}: 0.7039 \mathrm{~g} / \mathrm{cm}^{3}$ \\
& $\mathrm{TD}: 0.33-0.70 \mathrm{~g} / \mathrm{cm}^{3}$ & Carr's : $19.935 \%$ \\
Flow rate & $\leq 1.41 \mathrm{~g} / \mathrm{s}$ & Hausner $: 1.185$ \\
Angle of Repose & $34,4-49^{\circ}$ & $1.41645 \mathrm{~g} / \mathrm{s}$ \\
\end{tabular}

media can be used for beta-glucosidase inhibitor extraction process. After that, The samples were evaluated and three of them found had inhibitory effect toward cellulase enzyme. The process continued with cellulase enzyme extraction from fungi then it was mixed to inhibitors. Before the enzymatic hydrolysis process, the mixture of sample, cellulase, enzyme and enzyme inhibitor were tested to know the most desirable condition for the enzymatic hydrolysis process. The lowest glucose concentration was found in the optimization of acetate buffer solution $\mathrm{pH} 7$ at a temperature of $28^{\circ} \mathrm{C}$ (room temperature) with a duration of hydrolysis for $2 \mathrm{~h}$.

The manufacture of microcrystalline cellulose by enzymatic hydrolysis method of cellulase enzyme with addition of inhibitor was compared with enzymatic hydrolysis of cellulase enzyme without addition of inhibitor. When compared, the hydrolysis of microcrystalline cellulose samples from water hyacinth without the addition of inhibitor yield was $68 \%$, while with the addition of an inhibitor, the yield value obtained was $80 \%$.

From the characterization of microcrystalline cellulose samples, the result of hydrolysis is known that for organoleptic test, starch test, acidity degree, drying rate and flow rate test, it is known that the sample has met the existing requirement. But for ash level test, the test results do not meet the requirements because there are still a lot of residues of inorganic compounds derived from plants water hyacinth. To test the water content of the water content of the sample is higher than the existing conditions due to the nature of the powder is very hygroscopic, so it can easily absorb water in the environment. In addition, it can also be affected by the lack of dryness in the process of drying the powder after being hydrolyzed. For particle density test and rest angle, the results of microcrystalline cellulose powder samples fall into the excellent category. ${ }^{8}$

\section{CONCLUSION}

From the research it can be concluded that the isolates of the soil from the sediment in the mangrove forest have the potential to inhibit the activity of $\beta$ - glucosidase enzyme contained in the extract of cellulase enzyme; The optimum condition for enzymatic hydrolysis of the powder a - cellulose into microcrystalline cellulose is at $28^{\circ} \mathrm{C}$, with a duration of $2 \mathrm{~h}$, using acetate buffer $\mathrm{pH}$ 7. The addition of the inhibitor has an effect on the increase in the amount of microcrystalline cellulose yield produced from the result of enzymatic hydrolysis by inhibitors than without inhibitors; Identification with FTIR is known to resemble the standard; Characteristics of microcrystalline cellulose samples from water hyacinth compared to the Avicel PH 101 standard for organoleptic examination of the sample addressed similar but more yellowcolored; analysis with SEM shows a morphological similarity; analysis with XRD showed degree of crystallinity $67.47 \%$; The resulting powder is very smooth; qualitative analysis, starch test, acidity degree, drying shrinkage test meets the requirements; ash content, moisture content, particle density test, flow rate test and angle break test are almost the same as the standard.

There are identifications related to the type of mold that can be used as $\beta$ - glucosidase inhibitors of mangrove forests; it is necessary to make $\alpha$ - cellulose using more modern method; it is necessary to purify the cellulase enzyme extract; and microcrystalline cellulose purification process is required.

\section{ACKNOWLEDGEMENT}

Authors would like to thank Research Directorate of Universitas Indonesia for the re-search grant Hibah Publikasi Terindeks untuk Tugas Akhir (PITTA) 2018 which was given to our study. 


\section{REFERENCES}

1. Ahmed AF, Naby M. Pretreatment and enzymatic saccharification of water hyacinth cellulose. Carbohydrate Polymers. 2012.

2. Artati EK, Effendi A, Haryanto T. Pengaruh konsentrasi larutan pemasak pada proses delignifikasi eceng gondok dengan proses organosolv. Ekuilibrum. 2009;8(1):25-28.

3. Azubuike CP, Okhamafe AO. Physicochemical, spectroscopic and thermal properties of microcrystalline cellulose derived from corncobs. J Recyling Org Agric. 2012;1(9):1-7.

4. Onggo $H$, Tri Astuti J. Preparation and characterization of water hyacinth pulp. Telaah. 2018;XIX:1-6.

5. British Pharmacopoiea Volume I London: The Stationary Office. 2002.

6. Suryadi H, Sutriyo SS, Angeline M, Murti MW. Characterization of microcrystalline cellulose obtained from enzymatic hydrolysis of alpha-cellulose and its application. J Young Pharm. 2018;10(2s):S87-92.

7. Das K, Ray D, Bandyopadhyay NR, GhoshT, Mohanty AK, Misra M. A study of the mechanical, thermal and morphological properties of microcrystalline cellulose particles prepared from cotton slivers using different acid concentrations. Cellulose. 2009;16(5):783-93.

8. Horn SJ, Vaaje-Kolstad G, Westereng B, Eijsink VGH. Novel enzymes for the degradation of cellulose. Biotechnol Biofuels. 2012;5.

9. Park S, Baker JO, Himmel ME, Parilla PA, Johnson DK. Cellulose crystallinity index: Measurement techniques and their impact on interpreting cellulase performance. Biotechnology for Biofuels. 2010;3:1-14.
10. Kementerian Kesehatan Republik Indonesia. Farmakope Indonesia Edisi V. Jakarta: Direktorat Jenderal Bina Kefarmasian dan Alat Kesehatan Kementerian Kesehatan RI. 2014.

11. Ohwoavworhua F, Adelakun T, Okhamafe A. Processing pharmaceutical grade microcrystalline cellulose from groundnut husk: Extraction methods and characterization. Int J Green Pharm. 2009;3(2):97

12. Pandey S, Sree A, Dash S, Sethi D, Chowdhury L. Diversity of marine bacteria producing beta-glucosidase inhibitors. Microbial Cell Factories. 2013;12(1):35.

13. Rowe R, Raymond C, Sheskey, Paul J, Quinn E, Marian E. Handbook of pharmaceutical excipients. $6^{\text {th }}$ ed. Washington DC and London: American Pharmcist Association and Pharmaceutical Press. 2009.

14. Siqueira G, Bras J, Dufresne A. Cellulosic bionanocomposites: A review of preparation, properties, and applications. Polymers. 2010;2(4):728 -65.

15. Thoorens G, Krier F, Leclercq B, Carlin B, Evrard B. Microcrystalline cellulose, a direct compression binder in a quality by design environment - A review. Int J Pharm. 2014;473(1-2):64-72.

16. United States pharmacopeial convention. The United States pharmacopeia: The national formulary (31th ed.). Maryland: United States Pharmacopeial Convention. 2013

17. Xiao Z, Zhang X, Gregg DJ, Saddler JN. Effects of sugar inhibition on cellulases and $\beta$-glucosidase during enzymatic hydrolysis of softwood substrates. Appl Biochem Biotechnol - Part A Enzym Eng Biotechnol. $2004 ; 115(1-3): 1115-26$.

Cite this article: Shabrina A, Suryadi H, Sutriyo. Effects of Beta Glucosidase Inhibitor on Cellulase Enzyme Activity for Preparation of Microcrystalline Cellulose from Water Hyacinth (Eichhornia crassipes). Pharmacog J. 2019;11(6):1225-30. 